トピックス

\title{
自己組織化により生じる多細胞からなる構造の 人工的な形成
} 戸田 聡

Department of Cellular and Molecular Pharmacology, Center for Systems and Synthetic Biology, University of California San Francisco

\section{1.|はじめに}

多細胞生物の体は 1 つの受精卵からはじまり, 細胞 が多様な細胞種へ分化し，増殖や細胞死，パターン形 成などを繰り返すことで，体を構成する組織や臓器が 自律的に形成される。複雑な構造をした組織や臟器を 形成するために必要な遺伝プログラムは，各細胞のゲ ノム DNA 上に記録されている。近年のモデル生物を 用いた遺伝学や発生生物学の研究により, 発生時に機 能する遺伝子や細胞の動態が明らかにされてきた．細 胞が臓器などの巨視的な構造を自律的につくり出すた めのアルゴリズムを理解するためには，上述の研究に 加え，人工的な遺伝プログラムを設計し，実際に細胞 による組織形成過程をつくり出して検証する必要があ る.

細胞は，受容体を通して周囲の環境を感知すると， 細胞内分子によるシグナル伝達を介して，新たな遺伝 子発現や形態变化をアウトプットすることができる. ある細胞のアウトプットを別の細胞がインプットとし て感知することにより生じる細胞間コミュニケーショ ンは，細胞が集団行動をとり多細胞構造を形成するた めに重要である。しかし，どのような細胞間コミュニ ケーションを行えば，どのような形状の組織構造が形 成されるのか，については不明確なままであり，また この問いを体系的に検討する手法もなかった。 そこ で，私たちの研究室では，細胞間接触によるシグナル 伝達を行う Notch 受容体を改変し，インプットとし て認識する分子とアウトプットとして発現する遺伝 子を自在にプログラムすることができる人工受容体 “synthetic Notch receptor（synNotch）”を開発した (図 1A $)^{1)}$ 。本研究では, synNotch 受容体を用いて人 工的な細胞間コミュニケーションを設計し，細胞に自 律的に複雑な構造を形成させることをめざした22),3.

\section{2. 人工的な細胞間コミュニケーションの設計}

synNotch を発現する “Receiver 細胞” は， synNotch のリガンドを発現する “Sender 細胞”と接触すると， synNotch が活性化され，特定の遺伝子の発現を誘導 することができる，そこで，本研究では， synNotchを 用いた細胞間コミュニケーションに招いて，3 種類の

(A)

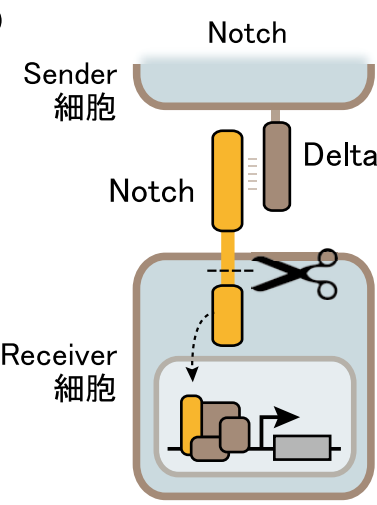

synNotch

(B)

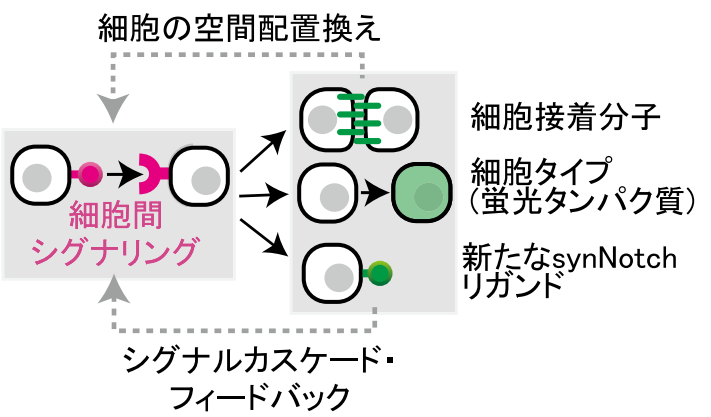

図 1

(A) synNotch システム. Notch 受容体は膜タンパク質 Delta と結 合すると, 張力により構造変化を起こし, 細胞膜付近でプロテ アーゼにより切断され，細胞内ドメインが核へと移行し遺伝子の 転写を引き起こす. synNotch は, Notch 受容体の細胞外ドメイン を任意のリガンドを認識する配列（一本鎖抗体など）に置き換え， 細胞内ドメインを特定の転写因子に置き換えることにより，任意 のリガンドを認識して任意の遺伝子の発現を誘導することができ る.（B）synNotch システムを用いた人工の細胞間コミュニケー ションの設計. 細胞接着による細胞の配置換えや新たな synNotch リガンドの誘導により, 新たな細胞間シグナル伝達を引き起こす.

Synthetic Morphogenesis: Programming Self-organizing Multicellular Structures Using Engineered Cell-cell Signaling Cascades Satoshi TODA

Department of Cellular and Molecular Pharmacology, Center for Systems and Synthetic Biology, University of California San Francisco 
アウトプット：(1)細胞の空間配置換えを引き起こす細

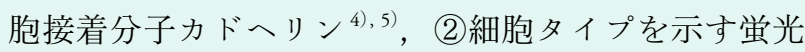
タンパク質, (3)新たなシグナル伝達を引き起こす synNotch リガンド，を誘導することにより，細胞が 高次構造へ自己組織化するプログラムを設計した (図 1B $)^{6}$. このプログラムをもともと特定の構造を形 成する能力をもたないマウス線維芽細胞株 L929 に導 入した. L929細胞は，超低接着性表面の丸底ウェル 上では，細胞どうしが中央に集まり，ゆるく結合した 細胞塊（スフェロイド）を形成する。そこで，L929細 胞が人工的な形態形成プログラムによりどのような構 造を形成するかを共焦点蛍光顕微鏡により観察した.

\section{3. 対称および非対称な多層構造の作製}

まず，Sender 細胞が synNotch を介して Receiver 細胞 にEカドヘリンおよびGFPの発現を誘導する細胞間コ ミュニケーションを設計した (図 2A上)。L929細胞は もともと CD19を発現していないため, Sender 細胞に はリガンドとして CD19を発現させ， Receiver 細胞に はCD19を認識する synNotch を用いた。 これらの細胞 を 100 個ずつ共培養したところ, Receiver 細胞は E カ ドヘリンを誘導して互いに強く結合し，スフェロイド の中心部に GFP を発現するコアを形成した. 一方，力 ドヘリンを発現しないSender細胞はコアの周辺に押し 出され，最終的に 2 層構造が形成された（図 2A下）.

より複雑な構造を形成するため, 最初の細胞間シグ ナルで 2 層構造を形成した後に, おくれて Receiver 細 胞から Sender 細胞へシグナル伝達が起こるシグナル カスケードを設計した（図 2B 上）。まず, Sender 細胞 がCD19を介して， Receiver 細胞の synNotch を活性化 し，高発現の E カドヘリンおよび GFPリガンド（GFP と膜貫通ドメインの融合タンパク質）の発現を誘導す る. その後, 誘導された GFP リガンドが Sender 細胞 上の synNotch を活性化し，低発現の E カドヘリンと mCherry を誘導する。 その結果, 最初のシグナル伝達 により，Eカドヘリンおよび GFPリガンドが誘導さ れた Receiver 細胞がコアを形成し，Sender 細胞は外層 を形成した，おくれて GFPリガンドによる 2 段階目 のシグナル伝達により，コアに接する Sender 細胞の みが活性化され， Eカドヘリンと mCherryを発現した 中間層が形成された。最終的に，Sender細胞および Receiver 細胞の 2 種類の細胞から，コア，中間層，外 層からなる 3 層構造が自己組織化された（図 2B下）.

動物の発生過程においては，体軸の形成など，極性 をもった非対称な肧構造が自発的に形成される。そこ で，非対称構造を作製するため， 3 層構造を形成する
(A)

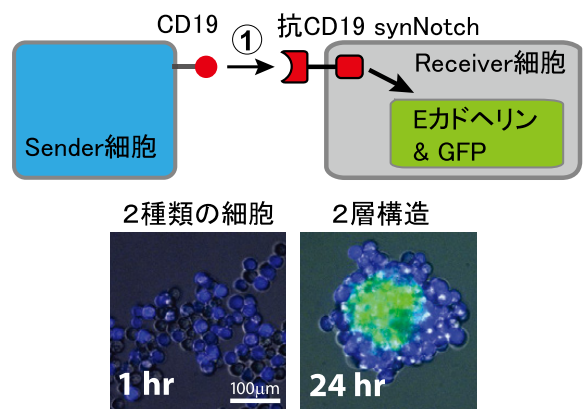

(B)

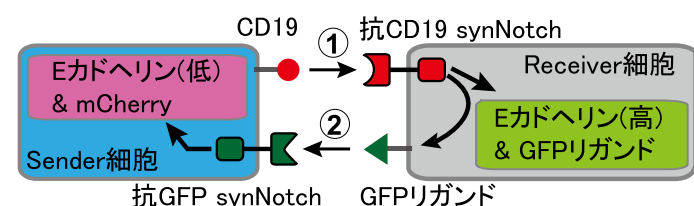

\section{2種類の細胞}

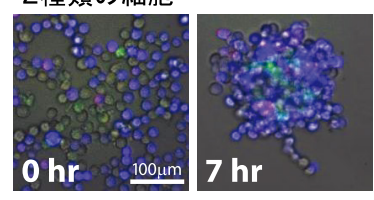

3層構造

図 2

（A）Eカドヘリンの発現の誘導による 2 層構造の自己組織化.（B） 異なる発現量のカドヘリンを段階的に誘導するシグナルカスケー ドによる 3 層構造の形成.

細胞間コミュニケーションにおいて，発現量の異なる $\mathrm{E}$ カドヘリンの代わりに異なる種類のカドヘリンを誘

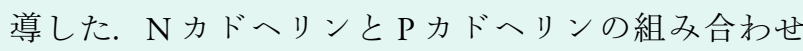
は，同種親和性は強いが異種親和性が弱いため， $\mathrm{N} カ$ ドヘリン発現細胞と P カドヘリン発現細胞を共培養 すると, 水と油が分離するように細胞集団の分離を引 き起こす。上述のシグナルカスケードでこれらのカド ヘリンを順に誘導し, 細胞集団の分離を引き起こすこ とで, 非対称で多様な形態の 3 層構造が形成された ${ }^{6)}$.

以上の人工的に作製した自己組織化過程の観察か ら，「細胞間でのシグナル伝達 $\rightarrow$ 細胞接着による細胞 の配置換え $\rightarrow$ 新たに隣接した細胞間でのシグナル伝 達」のサイクルにより, 細胞種類の増加をともなら複 雑な構造の形成が可能になると結論した。 また，創傷 治癒などでみられるょらに，多くの場合，組織は物理 的な損傷を受けた後に再生可能である。そこで，人工 的に作製した 3 層構造（図 2B）を物理的に切断し, その後どのように形態変化するかを観察した. マイク ロギロチン と) と呼ばれるマイクロ流路系を用いて 3 層 構造を真半分に切断したところ, 切断直後はコアを形 成している GFP 陽性の細胞が切断面に掞いて外部へ 露出していたが，時間とともに mCherry 陽性の中間層 によって再び包み込まれ，24時間後には 3 層構造が 再生可能であることが示された ${ }^{6)}$. 
synNotchを用いた側方抑制回路

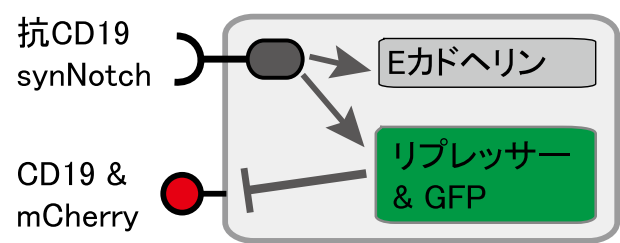

1 種類の細胞
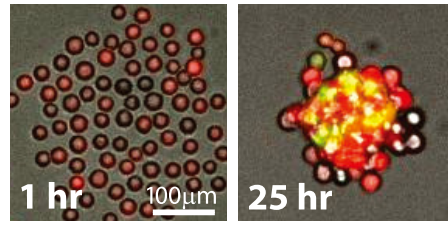

図 3

Eカドヘリンの発現を制御する側方抑制シグナル回路による 1 種 類の細胞からの 2 層構造の形成. CD19 の発現および synNotch の 活性化をモニターするため, CD19 は mCherry, リプレッサーは GFP とともに誘導される.

\section{1 種類の細胞から 2 層構造の作製}

動物の胚発生初期において，受精卵は細胞分裂を繰 り返した後，細胞運命が枝分かれし，内部細胞塊と栄 養膜からなる肧盤胞を形成する。そこで，均一な細胞 集団が 2 種類の細胞に枝分かれして形態形成する過程 を人工的につくり出すことをめざした．側方抑制と呼 ばれる細胞間シグナル回路は，均一な細胞集団から相 反する 2 種類の細胞の状態を生じさせることが知られ ている ${ }^{8)}$.たとえば，隣接する細胞間で互いにNotchを 介して Deltaの発現を抑制する側方抑制回路を導入す ると，均一な細胞集団が Delta 陽性かつ Notch 不活性 の細胞と Delta 陰性かつ Notch 活性化の細胞に二極化 する 。そこで, CD19を認識する synNotch が CD19 の発現を抑制するリプレッサーを誘導する側方抑制 回路をL929 細胞に導入し，さらにこの synNotch が CD19 の抑制に加え Eカドヘリンを誘導する回路を設 計した（図 3)。その結果，細胞は，CD19 陽性細胞 と, CD19陰性かつ synNotch 活性化かつEカドへリ ン陽性細胞に自発的に二極化した. 後者の細胞は $\mathrm{E}$ カドヘリンにより互いに強く結合してコアを形成し, CD19陽性細胞は外層に押し出され, 最終的に 1 種類 の均一な細胞集団から 2 層構造が自己組織化された.

\section{5. おわりに}

本研究では，細胞接着を制御する人工的な細胞間コ ミュニケーションにより, 外部からの制御を必要とし ない自己組織化，段階的にプログラムされた形態形成 過程, 細胞種類の増加, 非対称構造の形成, 物理切断 後の再生といった, 動物の発生でみられる重要な特徵 を再現することができた。 さらに今後は細胞接着に加 え, 動物の発生過程で重要な因子であるモルフォゲ ン， 細胞増殖や細胞死，細胞の分化転換などの新たな 要素を細胞間コミュニケーションに導入することで, より複雑で巧妙な人工組織を作製することが期待され る. 発生過程を人工的につくり出し, 細胞を特定の構 造へ自己組織化させる手法の開発は，単細胞生物が多 細胞生物へと進化するための十分条件の探索や自己修 復する生体材料の開発，改変細胞による組織修復をめ ざした再生医療などに有用である。

文 献

1) Morsut, L. et al. (2016) Cell 164, 780-791. DOI: 10.1016/ j.cell.2016.01.012.

2) Elowitz, M., Lim, W. A. (2010) Nature 468, 889-890. DOI: 10.1038/468889a.

3) Rubenstein, M. et al. (2014) Science 345, 795-799. DOI: 10.1126/ science. 1254295

4) Nose, A. et al. (1988) Cell 54, 993-1001. DOI: 10.1016/00928674 (88) 90114-6.

5) Vendome, J. et al. (2014) Proc. Natl. Acad. Sci. USA 111, E4175E4184. DOI: $10.1073 /$ pnas.1416737111.

6) Toda, S. et al. (2018) Science 361, 156-162. DOI: 10.1126/science. aat0271.

7) Blauch, L. R. et al. (2017) Proc. Natl. Acad. Sci. USA 114, 72837288. DOI: $10.1073 /$ pnas. 1705059114 .

8) Collier, J. R. et al. (1996) J. Theor. Biol. 183, 429-446. DOI: 10.1006/jtbi.1996.0233.

9) Matsuda, M. et al. (2015) Nat. Commun. 6, 6195. DOI: 10.1038/ ncomms 7195 .

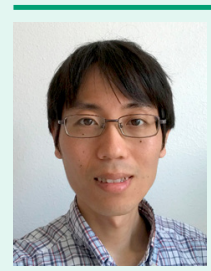

戸田 聡
戸田 聡（とだ さとし）

カリフォルニア大学サンフランシスコ校博士研究 員

2014 年京都大学大学院医学研究科を修了後, 同 年同博士研究員を経て 2015 年より現職. 研究内容:細胞を用いたものづくり

連絡先: Genentech Hall Room N414, 600 16th Street, San Francisco, CA 94158, USA

E-mail: satoshi.toda@ucsf.edu URL: http://limlab.ucsf.edu/index.html 